LINGUA, Vol. 17, No. 1, Maret 2020

p ISSN: 1979 9411; e ISSN: 2442 238X

Https://soloclcs.org; Email: presslingua@gmail.com

Center of Language and Cultural Studies, Surakarta, Indonesia

Wibowo, Iswanto Ari \& Cempaka, Gilang. (2020). Speech Act Classification and Request Strategy in "Tall Girl" Movie Directed by Nzingha Stewart.

Lingua (2020), 17(1): 25 34. DOI: 10.30957/lingua.v17i1.622.

\title{
Speech Act Classification and Request Strategy in "Tall Girl" Movie Directed by Nzingha Stewart
}

\author{
Ary Iswanto Wibowo ${ }^{1}$ \& Gilang Cempaka ${ }^{2}$ \\ Universitas Bina Sarana Informatika, Jakarta \\ Email: ${ }^{1}$ ary.anb@bsi.ac.id \& ${ }^{2}$ cempaka.glng@gmail.com
}

\begin{abstract}
The research is aimed to find out the speech act classification and types of request strategy from dialogue of the characters in Tall Girl movie. The method of this study is descriptive qualitative analysis. Data is taken out from all dialogues of the characters and is observed by using theories.In this analysis, the writers foundSpeech Act Classification and Types of Request Strategy in Speech Act. The speech act is classified in declaration, representatives, directives, commissives and expressives. Directives served the dominant form among the five types of illocutionary act mostly expressed their utterance. And as request strategy is typed in mood derivable, explicit performative, hedged performative, locution derivable, want statement, suggestory formula and prepatory. Mood derivable served the dominant form among theother types to deliver their willingness.
\end{abstract}

Keyword: speech act, request strategy

\section{Introduction}

Searle in (Katz, 2015), "speaking a language is performing speech acts, acts such as making statements, giving commands, asking questions, making promises and so on." The speaker speaks a language they also performing speech act. The acts include making statements, giving commands, asking questions, making promises and so on. Those acts performed as they speak a language.

Kent Bach in (Justová, 2006), "almost any speech act is really the performance of several acts at once, distinguished by different aspects of the speaker's intention: there is the act of saying something, what one does in saying it, such as requesting or promising, and how one is trying to affect one's audience." Speaker's intention distinguishing the acts that speaker's perform on speech act. For an example if speaker intent to request something, they will act differently from when they are intent to promise to their interlocutor and how the speaker persuade them.

As the conclusion, the writers conclude that speech act is the action that the speaker hopes to provoke in their interlocutor. When the speaker speaks a language they also performing speech act. In speech situation what we have to study is not the sentence but how the utterance is present. Speaker's intention distinguishing the acts that speaker's perform on speech act. The utterances could also deliver directly or indirectly. That is why speech acts are an important part of communication. 
LINGUA, Vol. 17, No. 1, Maret 2020

p ISSN: 1979 9411; e ISSN: 2442 238X

Https://soloclcs.org; Email: presslingua@gmail.com

Center of Language and Cultural Studies, Surakarta, Indonesia

Wibowo, Iswanto Ari \& Cempaka, Gilang. (2020). Speech Act Classification and Request Strategy in "Tall Girl" Movie Directed by Nzingha Stewart.

Lingua (2020), 17(1): 25 34. DOI: 10.30957/lingua.v17i1.622.

Speech act theory is a subfield of pragmatics. This area of study is concerned with the ways in which words can be used not only to present information but also to carry out actions.Speech act are used in everyday conversation not primarily to state the sentences we utter to one another, but it uses to carry out those utterances into action such as request. Request is a directive speech act whose illocutionary purpose is to get the interlocutors doing something in circumstances.

In this research, the writers will focus on the dialogue in Tall Girl movie to be classified in accordance with the speech act classification theory and the types of request strategy. Tall Girl is a 2019 American romantic comedy film about fitting in that's set in high school. The movie tells about the pressure to conform can be overwhelming with friendship and family support. Furthermore, it is directed by Nzingha Stewart, from a screenplay by Sam Wolfson. The film stars Ava Michelle, Griffin Gluck, Sabrina Carpenter, Paris Berelc, Luke Eisner, Clara Wilsey, Anjelika Washington, Rico Paris, Angela Kinsey, and Steve Zahn. It was released by Netflix on September 13, 2019.

\section{Research Questions}

The writers state some of the problems in the following questions as follow:

1. What are dialogues classified in speech act?

2. What are the requests strategy of speech act used in the Tall Girl movie?

\section{Methods}

\subsection{Research Design}

Moleong written in (Rangga, Nalendra, Wulandari, Khoirunnada, \& Susanti, 2018), define "Descriptive research is a type of research which does not use calculation or numerating. This method is implemented to reach the objectives of the research". It means that this paper using method that observe and describe the result with words, it doesn't use any calculation formula to achieve its result. It also means the method delivers the objectives of the study not the subjective writers' opinion.

This research is classified as a descriptive qualitative method as the technique to observe the data. The descriptive technique is used to analyse speech act classification and the types of request strategy in Tall Girl movie by describing the data in order to tell dialogue belong to speech act classification and request strategy.Data is taken out from the dialogue of the characters in this movie that contains speech act classification and request strategy.

The classification of illocutionary acts propose by Searle is a development of ideas that appears in Austin's theory. According to Searle in (Katz, 2015), illocutionary speech acts can also be broken down into different classification, grouped together by their intent of usage there are five classification of speech act:

A. Declaration are the speech acts in which the speaker aims to change theworld via his/her utterances. 
B. Representatives are the speech acts in which the speaker asserts a propositionto be true.

C. Directives are the speech acts in which the speaker tries to make thehearer do something, such as requesting. Based on the research results, there are 86 utterances belongs to directives. With 34 utterance belong to requesting itself.

D. Commissives are the speech acts in which the speaker commitshimself/herself to a future course of action.

E. Expressives are the speech acts in which the speaker expresses an attitude to or about a state of affairs.

\subsection{Request Strategy}

Wierzbicka states in (Sari, 2017),"request is used in some conditions where the speaker wants to get the addressee to do something." It means request is an imposition to the interlocutor, where the interlocutor asked to fulfil the speaker wants. In this study, the writers refers to the similar concept of request strategies proposed by Blum-Kulka and House, Kasper in (Sari, 2017). They classified request into nine types: mood derivable, explicit performative, hedged performative, locution derivable, want statement, suggestory formula, prepatory, strong hint, and mild hint.

Request strategy types according to Blum-Kulka and House, Kasper in (Sari, 2017) are:

A. Mood Derivable

The grammatical mood of the locution conventionally determines its illocutionary force as a request. It means that the verb in request can described the mood of requester directly.

B. Explicit Performative

The illocutionary intent is explicitly named by the speaker by using a relevant illocutionary verb. The request is described in direct way and it is clear by using the word request itself, such as ask.

C. Hedged Performative

The illocutionary verb denoting the requestive intent is modified, such as by using modal verbs or verbs expressing intention.

D. Locution Derivable

The illocutionary intent is directly derivable from the semantic meaning of the locution.

E. Want Statement

The utterance expresses the speaker's desire that the event denoted in the proposition come about. The speaker described his willingness about thing in request.

F. Suggestory Formula

This is the utterances that contain suggestion to do something. The speaker asks the hearer by the suggestion meaning.

G. Prepatory 
LINGUA, Vol. 17, No. 1, Maret 2020

p ISSN: 1979 9411; e ISSN: 2442 238X

Https://soloclcs.org; Email: presslingua@gmail.com

Center of Language and Cultural Studies, Surakarta, Indonesia

Wibowo, Iswanto Ari \& Cempaka, Gilang. (2020). Speech Act Classification and Request Strategy in "Tall Girl" Movie Directed by Nzingha Stewart.

Lingua (2020), 17(1): 25 34. DOI: 10.30957/lingua.v17i1.622.

The utterance contains reference to a prepatory condition for the feasibility of the request, typically one of ability, willingness, or possibility, as conventionalized in the given language. It means the speaker makes a preparation to do the request, preparing for the hearer to response his requesting.

H. Strong Hint

The illocutionary intent is not immediately derivable from the locution; however, the locution refers to relevant elements of the intended illocutionary and/or propositional act. In this type the speaker does the request directly.

I. Mild Hint

The utterance is not put the obligation to do something but the context will strengthen the demand. The requesting in this type is said implicitly.

\section{Results and Discussion}

The analysis of the story describes the results of the data analysis to focus on the dialogue to be classified in accordance with the speech act classification theory and the types of request strategy from dialogue speech act.

\subsection{Types of Speech Acts \\ 1. Declaration}

Based on the research results an utterance that classified as declaration appear in the homecoming King and Queen school event announced by Harper, Jody's sister and Ms. Minnesota at a time.

Harper: And now, without further ado, your Homecoming King and Queen. Thank you. And the winner is Kimmy Stitcher and StigMohlin.

The utterance "your Homecoming King and Queen.the winner is Kimmy Stitcher and StigMohlin." above containsdeclaration, which Harper declared KimmyStitcher and StigMohlinas Homecoming King and Queen. Declarations bring about some alternation in the status or condition of the person whose been declared that makes the declaration has been successfully performed. The utterance above defines the characteristic of this class that the successful performance of the speaker brings the alternation reality and status of the person whose been declared. Harper successfully perform the act of appointing KimmyStitcher and StigMohlinas Homecoming King and Queen.

\section{Representatives}

Based on the research results a sample of utterance that identified as representatives appear in the conversationbetween Jodi and Kimmy below.

Jodi: Okay, I'm not falling for another one of your tricks.

Kimmy: It's not a trick.He told me to come over and invite you. 
The utterance "It's not a trick." above belongs to representatives.Kimmy expressed the truth or fact that she doesn't want to trick Jodi in which generally accepted by Jodi because of the reason she told in the next sentence "He told me to come over and invited you." aim to tell that Schnipper who is told Kimmy to invite Jodi. Based onSearle's definition, speaker's utterance that says something about the truth or fact belongsto representatives types of illocutionary act.

\section{Directives}

Based on the research results a sample of utterance that identified as directives appear in the conversationbetween Kimmy and Stig below.

Kimmy: Stiggy, baby, would you mind getting Mama a Diet Slice before class?

Stig: Yeah. Sure. See ya, Jodi.

The utterance "would you mind getting Mama a Diet Slice before class?" above belongs to directives.Directives are used by the speaker to get someone to do something. Kimmy utterance "would you mind getting Mama a Diet Slice before class?" aims to make Stig to get her a sandwich. "would you mind" and "please" indicate the sentence contains a request.Based on Searle's definition, kind of illocutionary act that attempts by the speaker to get the hearer to do something are called directives.

\section{Commissives}

Based on the research results a sample of utterance that identified as refusing appear in the conversationbetween Jack and Jodi below.

Jack: So David Blaine called me, you'll never believe it. He wants to know when you and I will make magic together.

Jodi: You do this everyday. Dunkleman, it's never gonna happen.

The utterance "it's never gonna happen." above belongs to commissives. The word "never" and "gonna" means that Jodi commits herself to Jack that she and Jack being together is not going to happen. Based on Searle's definition, speaker's utterance that the speaker commits himself/herself to a future course of action are called commissives.

\section{Expressives}

Based on the research results a sample of utterance that identified as expressives appear in the conversationbetween Jodi's Mom and Harper below.

Mom: Oh! I love it! That's the one. 
Harper: But I have 27 more upstairs.

The utterance "Oh! I love it! That's the one." above belongs to expressives. The word "love" indicate that the sentence contains a like. So Jodi's Mom expresses her like on the outfit to Harper. Based on Searle's definition, speaker's utterance that the speaker expresses an attitude to or about a state of affairs are called expressives.

\subsection{Types of Request Strategy in Speech Act}

Based on the research results, there were seven strategies found. There are mood derivable, explicit performative, hedged performative, locution derivable, want statement, suggestory formula, and prepatory.The strategy which not appeared were strong hint and mild hint.

\section{Mood Derivable}

Based on the research results a sample of utterance that identified as mood derivable appear in the conversationbetween Jodi and Harper below.

Jodi: Not so sure about that.

Harper: Jodi!Listen to me, okay? If I had that kind of attitude, I don't think I ever would've gotten that job with the Hilton Corporation.

The utterance "Listen to me" above belongs to mood derivable. Harper uses mood derivable strategy in delivering her willingness, where the speaker speaks directly about her desire. Harper straightforwardly asks Jodi to listen to her. She says "listen", it means she wants to be heard.

\section{Explicit Performative}

Based on the research results a sample of utterance that identified as explicit performative appear in Principal Preston announcement on the stage.

Principal Preston: This is the moment you've all been waiting for, the announcement of your Homecoming King and Queen. And to read the names, please help me welcome to the stage Ruby Bridges alum and recently-crowned Teen Miss Louisiana, Harper Kreyman.

The utterance "please help me welcome to the stage" above belongs to explicit performative. Principal Preston uses explicit performative strategy in delivering her willingness, where the speaker speaks directly about her desire with relevant illocutionary verb. Principal Preston straightforwardly asks students to help him. He says "please help", using the word request itself asking for help. 


\section{Hedged Performative}

Based on the research resultsasample of utterance that identified as hedge performative appear in the conversationbetween Jodi and Harper below.

Jodi: Okay, fine. Um, but I... I need your help with something.

Harper: Sure, what's up?

The utterance "I need your help with something." above belongs to hedge performative. As seen in this dialogue, Jodi performs her request directly by using modal "need". The modal and verb "help" indicate that the request is included in hedged performative strategy.

\section{Locution Derivable}

Based on the research results a sample of utterance that identified as locution derivable appear in the conversationbetween Stig and Jack below.

Stig: It was different than when I kiss Kimmy. It was really good, Dunkers. It was intense and passionate, and I could feel her heart...

Jack: Cool. That's enough, you can stop now.

The utterance "you can stop now." above belongs to locution derivable. As seen in this dialogue, Jack performs her request second person as the subject and using a modal "can". The second person as the subject, modal and verb "stop" indicate that the request is included in locution derivable strategy.

\section{Want Statement}

Based on the research results a sample of utterance that identified as want statement appear in the conversationbetween Jodi and her Dad below.

Jodi's Dad: Jodi, I just want you to feel normal.

Jodi: Don't you realize that... that every time you try to make me feel more normal, you just end up making me feel like more of a freak?

The utterance "I just want you to feel normal." above belongs to want statement. In this sentence it can be seen that the requester in this dialogue uses want statement strategy, where the speaker says his feeling and desired directly. The verb "want" indicates that the speaker wants the hearer to approve his desired.

\section{Suggestory Formula}

Based on the research resultsasample of utterance that identified as want suggestory formula in the conversationbetween Jodi's Mom and Harper below. 
LINGUA, Vol. 17, No. 1, Maret 2020

p ISSN: 1979 9411; e ISSN: 2442 238X

Https://soloclcs.org; Email: presslingua@gmail.com

Center of Language and Cultural Studies, Surakarta, Indonesia

Wibowo, Iswanto Ari \& Cempaka, Gilang. (2020). Speech Act Classification and Request Strategy in "Tall Girl" Movie Directed by Nzingha Stewart.

Lingua (2020), 17(1): 25 34. DOI: 10.30957/lingua.v17i1.622.

Harper: What do you think of this one?

Mom: Hmm. Let me see it with the wave.

The utterance "Let me see it with the wave." above belongs to suggestory formula. The speaker asks the hearer by the suggestion meaning. Blum Kulka, House and Kasper classified it into suggestory formula.

\section{Prepatory}

Based on the research resultsasample of utterance that identified as want prepatory in the conversationbetween Jodi's Schnipper and Jodi below.

Schnipper: Hello? Hi, may I speak with Jodi, please?

Jodi: Uh, yeah. Yeah, this is Jodi

The utterance "may I speak with Jodi, please?" above belongs to prepatory. Looking at the way Schnipperasks using the modal "may" in the question. The modal and the question mark included in type of preparatory strategy. Thespeaker seems to ask the hearer on her availability.

\section{Conclusion and Suggestions}

The conclusion obtained from the findings and results of data analysis on the focus of the first problemon Tall Girl movie are dialogues classified in speech act classification leads to the theory of John Searle.Having analyzed this movie, the writers found utterances contain illocutionary act categorized as declaration, representatives, directives, commissives, and expressives. From the data above, directives served the dominant form among the five types of illocutionary act mostly expressed their utterance.The conclusion of the second problem, the writers decide request from dialogue speech act in Tall Girl movie by using Blum-Kulka and House, Kasper theory.Having analyzed this movie, the writers found utterances belongs to requesting and almost all strategies applied by the characters in their communication, such as mood derivable, explicit performative, hedged performative, locution derivable, want statement, suggestory formula, and prepatory. Only two strategies which are not appliedthey are strong hint and mild hint. From the result in can be concluded that Tall Girl movie dialogue speech actprefer to use mood derivablestrategy to deliver their willingness.

\section{References}

Alterman, A. (2001). The New Wittgenstein (review). In Journal of the History of Philosophy (Vol. 39). https://doi.org/10.1353/hph.2003.0116

Boggs, J. M., \& Petrie, D. W. (2008). The Art of Watching Films. In Structure. Retrieved from http://eric.ed.gov/ERICWebPortal/recordDetail?accno=ED398157 
LINGUA, Vol. 17, No. 1, Maret 2020

p ISSN: 1979 9411; e ISSN: 2442 238X

Https://soloclcs.org; Email: presslingua@gmail.com

Center of Language and Cultural Studies, Surakarta, Indonesia

Wibowo, Iswanto Ari \& Cempaka, Gilang. (2020). Speech Act Classification and Request Strategy in "Tall Girl" Movie Directed by Nzingha Stewart.

Lingua (2020), 17(1): 25 34. DOI: 10.30957/lingua.v17i1.622.

Halliday, M. A. K. (2006). On Language and Linguistic (1st ed.; J. Webster, Ed.). London: Continuum.

Inayah Kurnia. (2017). The Article Introduction To Linguistic. Universitas Diponegoro Semarang.

Justová, V. (2006). Direct and indirect speech acts in English. 1-45.

Katz, M. H. (2015). Politeness theory and the classification of speech acts. Working Papers of the Linguistic Circle of the University of Victoria, 25(2), 45-55.

Korta, K., \& Perry, J. (2019). Pragmatics. Retrieved from Standford Encyclopedia of Philosophy website: https://plato.stanford.edu/entries/pragmatics/

Kracht, M. (2009). Compositionality: the very idea. 1-26.

Mahmood, R. K. (2017). Pragmatics between Microlinguistic and Macrolinguistic Levels of analysis. Global Journal of Foreign Language Teaching, 6(3), 127. https://doi.org/10.18844/gjflt.v6i3.1659

Nordquist, R. (2019). Speect Acts in Linguistic. Retrieved from ThoughtCo. website: https://www.thoughtco.com/speech-act-linguistics-1692119

Oxford. (2020). US Dictionary. Retrieved from Lexico website: https://www.lexico.com/en/definition/microlinguistics

Pradiyan Hendi Yulianto. (2013). Request Strategies Used in Twilight Novel by Stephenie Meyer (A Pragmatif Approach). Muhammadiyah University of Surakarta.

Rangga, A., Nalendra, A., Wulandari, A., Khoirunnada, M., \& Susanti, I. D. (2018). AN ANALYSIS OF ADDRESSING TERM IN USED IN THE LOVE. XIII(2), 9-16.

Sari, D. R. (2017). request strategies in Pride and Prejudice movie. Jurnal KATA, 1(1), 24. https://doi.org/10.22216/jk.vli1.1746

Silalahi, P. V. (2016). A Highlight on Pragmatics. Universitas 17 Agustus 1945 Surabaya, 16(01), 83-92.

Tanriverdi, B. (2007). Film Analysis through Linguistic Base. Online Submission.

Tröhler, M. (2018). 1. Christian Metz and Film Semiology Dynamics within and on the Edges of the 'Model': An Introduction. In Christian Metz and the Codes of Cinema. https://doi.org/10.1515/9789048527564-003 
LINGUA, Vol. 17, No. 1, Maret 2020

p ISSN: 1979 9411; e ISSN: 2442 238X

Https://soloclcs.org; Email: presslingua@gmail.com

Center of Language and Cultural Studies, Surakarta, Indonesia

Wibowo, Iswanto Ari \& Cempaka, Gilang. (2020). Speech Act Classification and Request Strategy in "Tall Girl" Movie Directed by Nzingha Stewart.

Lingua (2020), 17(1): 25 34. DOI: 10.30957/lingua.v17i1.622. 